\title{
A Novel Method for the Preparation of Nucleoside Triphosphates from Activated Nucleoside Phosphoramidates
}

Weidong Wu, Caren L. Freel Meyers and Richard F. Borch*

Department of Medicinal Chemistry and Molecular Pharmacology and Cancer Center,

Purdue University, West Lafayette, Indiana 47907

\section{Supporting Information}

\section{Table of Contents}

Experimental procedure: $\quad 2-9$

${ }^{1} \mathrm{H}$ and ${ }^{31} \mathrm{P}$ NMR of compound 4c: $\quad 10$

${ }^{1} \mathrm{H}$ and ${ }^{31} \mathrm{P}$ NMR of compound 4d: $\quad 11$

${ }^{1} \mathrm{H}$ and ${ }^{31} \mathrm{P}$ NMR of compound 4e: $\quad 12$

$1 \mathrm{H}$ and ${ }^{31} \mathrm{P}$ NMR of compound $\mathbf{5 d :} \quad 13$

${ }^{1} \mathrm{H}$ and ${ }^{31} \mathrm{P}$ NMR of compound 5e: $\quad 14$

HPLC of compound 5d, 5e: $\quad 15$ 


\section{General experimental}

Routine ${ }^{1} \mathrm{H},{ }^{13} \mathrm{C}$ NMR spectra were recorded using standard methods and are referenced to the solvent. ${ }^{31} \mathrm{P}$ NMR spectra were acquired using broadband gated decoupling and are referenced using 1\% triphenylphosphine oxide in benzene- $d 6$ as the coaxial reference (triphenylphosphine oxide/ benzene- $d_{6}$ has a chemical shift of +25.17 ppm relative to $85 \%$ phosphoric acid). ${ }^{31} \mathrm{P}$ NMR spectra of synthesized nucleoside triphosphates were taken in $10 \mathrm{mM}$ NaEDTA to suppress trace metal line broadening.

Analytical TLC on silica gel was performed on polyester plates coated with silica gel $60 \mathrm{~F}_{254}$ and were visualized by UV light or 5\% phosphomolybdic acid in ethanol spray. Flash silica gel chromatography was performed on silica gel 60 (230-400 mesh). Analytical HPLC analyses for nucleoside triphosphates were performed using an Adsorbsphere ${ }^{\circledR}$ Nucleotide-Nucleoside column (Alltech) on a Beckman System Gold equipped with 128 Solvent Module and 168 Detector. The elution was carried out at 1.0 $\mathrm{mL} / \mathrm{min}$ with a gradient from $5 \% \mathrm{CH}_{3} \mathrm{CN} / 60 \mathrm{mM} \mathrm{KH}_{2} \mathrm{PO}_{4} / 4 \mathrm{mM}$ TBAP, $\mathrm{pH} 5.0$ to $22 \%$ $\mathrm{CH}_{3} \mathrm{CNl} / 60 \mathrm{mM} \mathrm{KH} \mathrm{PO}_{4} / 4 \mathrm{mM}$ TBAP, $\mathrm{pH} 6.0$ over 10 min with UV detection at $254 \mathrm{~nm}$ (230 $\mathrm{nm}$ for ribavirin 5'-triphosphate $\mathbf{5 d}$ )

Anhydrous solvents were either distilled from appropriate drying agents or obtained from commercial source. 2',3'-O -Methoxymethylidene-uridine was synthesized using a modified procedure of Davisson, et al.. ${ }^{1}$ Ribavirin (1- $\beta$-D-ribofuranosyl-1,2,4-triazole-3carboxamide) was synthesized according to the reported procedure. ${ }^{2} N^{4}$ (allyloxycabonyl)cytosine arabinoside was synthesized according to the reported procedure. $^{3}$ Tributylammonium pyrophosphate was purchased from Sigma and tris(tetra$n$-butylammonium) hydrogen pyrophosphate was prepared according to the reported procedure. ${ }^{4}$ All other chemical reagents were obtained from commercial sources.

1-( $\beta$-D-ribofuranosyl-2',3'- $O$-Methoxymethylidene)-1,2,4-triazole-3-carboxamide (6d). Ribavirin ${ }^{2}$ (122 mg, $\left.0.5 \mathrm{mmol}\right), p$-toluenesulfonic acid (38 mg, $0.2 \mathrm{mmol}$ ) and pyridine $(16 \mu \mathrm{L}, 0.2 \mathrm{mmol})$ were stirred in THF $(2 \mathrm{~mL})$ at room temperature. Trimethyl

\footnotetext{
${ }^{1}$ Davisson, V. J.; Davis, D. R.; Dixit, V. M.; Poulter, C. D. J. Org. Chem. 1987, 52, 1794-1801; Griffin, B. E.; Jarman, M.; Reese, C. B.; Sulston, J. E. Tetrahedron 1967, 23, 2301-2313.

${ }^{2}$ Witkowski, J. T., Robins, R. K., Sidwell, R. W., Simon, L. N., J. Med. Chem., 1972, 15, 1150-54.

${ }^{3}$ Tobias, S. C., Borch, R. F., Mol. Pharmaceutics, 2004, 1, 112-116.

${ }^{4}$ Davisson, V. J.; Davis, D. R.; Dixit, V. M.; Poulter, C. D. J. Org. Chem. 1987, 52, 1794-1801.
} 
orthoformate $(0.27 \mathrm{~mL}, 2.5 \mathrm{mmol})$ was added via syringe, and the mixture was stirred overnight. The reaction mixture was concentrated in vacuo and the residue was purified by silica gel chromatography (methylene dichloride/methanol, 20:1 to 10:1) to yield $6 \mathbf{d}$ as a white foam (120 mg, 84\%, mixture of two diastereomers as shown by $\left.{ }^{1} \mathrm{H} \mathrm{NMR}\right)$. TLC: $R_{f} 0.35$ (methylene chloride/methanol, 10:1). ${ }^{1} \mathrm{H}$ NMR (DMSO-d 6 , $300 \mathrm{MHz}$ ) for diastereomers: $\delta 8.84,8.80$ (s, $1 \mathrm{H}, \mathrm{H}-5), 7.86,7.65$ (s, 2H, $\left.\mathrm{CONH}_{2}\right), 6.27,6,24(\mathrm{~d}, 1 \mathrm{H}$, , H-1'), 6.13, 6.03 (s, 1H, acetal), 5.25 (m, 1H, H-2'), 5.01 (m, 1H, H-3'), 4.27 (m, 2H, H4'), 3.40 (m, 2H, H-5', H-5'), 3.34, 3.22 (s, 3H, $\mathrm{OCH}_{3}$ ). HRMS (ESI): Calcd for $\mathrm{C}_{10} \mathrm{H}_{14} \mathrm{~N}_{4} \mathrm{NaO}_{6} 309.0811[\mathrm{M}+\mathrm{Na}]^{+}$; Found: 309.0816.

\section{5'-Uridyl 1-benzotriazolyl $N$-methyl- $N$-(4-chlorobutyl) phosphoramidate (9c).}

Phosphoramidic dichloride 7 (1.53 g, $6.4 \mathrm{mmol})$ was dissolved in THF (5 mL) and added dropwise to a stirred solution of 1-hydroxybenzotriazole (1.73 g, $12.8 \mathrm{mmol})$ and pyridine $(1.04 \mathrm{~mL}, 12.8 \mathrm{mmol})$ in THF $(10 \mathrm{~mL})$ at room temperature under argon. The reaction mixture was stirred for $4 \mathrm{~h}$; at this time ${ }^{31} \mathrm{P}$ NMR indicated that bisbenzotrizolyl phosphoramidate 8 was formed $(-11.93 \mathrm{ppm})$. The reaction mixture was centrifuged at $10,000 \mathrm{rpm}$ for $10 \mathrm{~min}$ to remove pyridine hydrochloride, and the supernatant containing 8 was added to a stirred solution of 2', '3'-O -Methoxymethylidene-uridine ${ }^{1} \mathbf{6 c}(0.45 \mathrm{~g}, 1.6$ $\mathrm{mmol})$ in pyridine $(5 \mathrm{~mL})$ at room temperature. 1-Methylimidazole $(0.51 \mathrm{~mL}, 6.4 \mathrm{mmol})$ was added to the above solution and the reaction mixture was stirred overnight at room temperature under argon. Solvent was removed in vacuo, and the residue was dissolved in methylene chloride $(100 \mathrm{~mL})$, washed with saturated $\mathrm{NH}_{4} \mathrm{Cl}$ solution $(50 \mathrm{~mL})$ and the organic layer was dried over anhydrous $\mathrm{Na}_{2} \mathrm{SO}_{4}$ and concentrated in vacuo. The residue was purified by silica gel chromatography (methylene chloride/ethyl alcohol 40:1 to 20:1) to give 9c (690 mg, 75\%, mixture of diastereomers as indicated by ${ }^{1} \mathrm{H}$ and ${ }^{31} \mathrm{P} \mathrm{NMR}$ ) as a white foam. TLC: $R f \quad 0.65$ (methylene chloride/methanol, 10:1); ${ }^{1} \mathrm{H} \mathrm{NMR}\left(\mathrm{CDCl}_{3}, 300\right.$ MHz) for diastereomers: $\delta 7.98(\mathrm{~d}, 1 \mathrm{H}, \mathrm{H}-6), 7.71-7.36(\mathrm{~m}, 4 \mathrm{H}, \mathrm{Ph}-\mathrm{H}), 5.89(\mathrm{~d}, 1 \mathrm{H}$, acetal), 5.78 - 5.66 (m, 2H, H-5, H-1') $4.98-4.80$ (m, 2H, H-2', H-3'), 4.48 (m, 3H, H4', H-5' and H-5' '), 3.47 (m, 2H, $\left.\mathrm{ClCH}_{2}-\right)$, 3.37(d, 3H, $\left.-\mathrm{OCH}_{3}\right), 3.12\left(\mathrm{~m}, 2 \mathrm{H},-\mathrm{CH}_{2}-\mathrm{N}\right)$, $2.82\left(\mathrm{dd}, 3 \mathrm{H}, \mathrm{CH}_{3}-\mathrm{N}\right), 1.64\left(\mathrm{~m}, 4 \mathrm{H},-\mathrm{CH}_{2} \mathrm{CH}_{2}-\right) ;{ }^{31} \mathrm{P} \mathrm{NMR}\left(\mathrm{CDCl}_{3}, 121 \mathrm{MHz}\right) \delta-12.98$, -13.31 (1:1); MS (ESI): 587/589 [M +H] $]^{+}$, HRMS (ESI): calcd for $\mathrm{C}_{22} \mathrm{H}_{29} \mathrm{ClN}_{6} \mathrm{O}_{9} \mathrm{P}$ $587.1422[\mathrm{M}+\mathrm{H}]^{+}$, found 587.1434. 


\section{5'-[1-( $\beta$-D-ribofuranosyl-2',3'-O-Methoxymethylidene)-1,2,4-triazole-3-}

carboxamide] 1-benzotriazolyl $N$-methyl- $N$-(4-chlorobutyl) phosphoramidate (9d).

Following the same procedure described for synthesis of 9c, bisbenzotriazolyl phosphoramidate 8, generated by the reaction of phosphoramidic dichloride $7(2.65 \mathrm{~g}$, $11.1 \mathrm{mmol})$ with 1-hydroxybenzotriazole $(3.0 \mathrm{~g}, 22.2 \mathrm{mmol})$ and pyridine $(1.8 \mathrm{~mL}, 22.2$ $\mathrm{mmol})$ in THF $(15 \mathrm{~mL})$ at room temperature for $4 \mathrm{~h}$ under argon, was added to a solution of protected ribavirin $\mathbf{6 d}(530 \mathrm{mg}, 1.85 \mathrm{mmol})$ and $N$-methylimidazole $(0.88 \mathrm{~mL}, 11.1$ $\mathrm{mmol})$ in pyridine $(5 \mathrm{~mL})$, and the reaction mixture was stirred for $24 \mathrm{~h}$ at room temperature under argon. Same workup and purification by silica gel chromatography (Hexane/ethyl acetate/methanol, 5:5:1) gave 9d (810mg, 75\%, mixture of diastereomers as indicated by ${ }^{1} \mathrm{H}$ and ${ }^{31} \mathrm{P} \mathrm{NMR}$ ) as a white foam. TLC: $R f \quad 0.20$ (Hexane/ethyl acetate/methanol, 5:5:1); ${ }^{1} \mathrm{H} \mathrm{NMR}\left(\mathrm{CDCl}_{3}, 300 \mathrm{MHz}\right)$ for diastereomers: $\delta 8.28(\mathrm{~d}, 1 \mathrm{H}$, H-5), $7.94-7.31$ (m, 4H, Ph-H), 6.08 - 5.80 (m, 3H, acetal, H-5 and H-1'), 5.31 - 4.96 (m, 2H, H-2', H-3'), 4.68 - 4.20 (m, 3H, H-4', H-5' and H-5' '), 3.39 (m, 2H, $\mathrm{ClCH}_{2}-$ ), 3.26(m, 3H, $\left.-\mathrm{OCH}_{3}\right), 2.96\left(\mathrm{~m}, 2 \mathrm{H},-\mathrm{CH}_{2}-\mathrm{N}\right), 2.71\left(\mathrm{~m}, 3 \mathrm{H}, \mathrm{CH}_{3}-\mathrm{N}\right), 1.55(\mathrm{~m}, 4 \mathrm{H}$, $\left.-\mathrm{CH}_{2} \mathrm{CH}_{2}-\right)$; ${ }^{31} \mathrm{P}$ NMR $\left(\mathrm{CDCl}_{3}, 121 \mathrm{MHz}\right) \delta$-13.48, -13.61 (1:1); MS (ESI): 587/589 $[\mathrm{M}+\mathrm{H}]^{+}, 609 / 611[\mathrm{M}+\mathrm{Na}]^{+} ; \quad \mathrm{HRMS}(\mathrm{ESI})$ : calcd for $\mathrm{C}_{21} \mathrm{H}_{28} \mathrm{ClN}_{8} \mathrm{NaO}_{8} \mathrm{P}$ 609.1354 [M $+\mathrm{Na}]^{+}$, found 609.1352 .

\section{5'-[N4-(Allyloxycarbonyl)cytosine arabinosyl] 1-benzotriazolyl $N$-methyl- $N$-(4-} chlorobutyl) phosphoramidate (9e). Following the procedure described for synthesis of 9c, bisbenzotriazolyl phosphoramidate $\mathbf{8}$, generated by the reaction of phosphoramidic dichloride $7(1.09 \mathrm{~g}, 4.6 \mathrm{mmol})$ with 1-hydroxybenzotriazole $(1.24 \mathrm{~g}, 9.2 \mathrm{mmol})$ and pyridine $(0.74 \mathrm{~mL}, 9.2 \mathrm{mmol})$ in THF $(10 \mathrm{~mL})$ at room temperature for $4 \mathrm{~h}$ under argon, was added to a solution of $N^{4}$-(allyloxycabonyl)cytosine arabinoside ${ }^{3}$ 6e $(500 \mathrm{mg}, 1.53$ mmol) and $N$-methylimidazole $(0.24 \mathrm{~mL}, 3.06 \mathrm{mmol})$ in pyridine $(5 \mathrm{~mL})$, and the reaction mixture was stirred for $6 \mathrm{~h}$ at room temperature under argon. The reaction was quenched by adding methylene chloride $(100 \mathrm{~mL})$ and saturated $\mathrm{NH}_{4} \mathrm{Cl}$ solution $(50 \mathrm{~mL})$. The organic layer was separated and dried over anhydrous $\mathrm{Na}_{2} \mathrm{SO}_{4}$. Solvent was removed in vacuo and the residue was purified by silica gel chromatography (methylene chloride/ethanol, $20: 1$ to $10: 1)$ to give $9 \mathrm{e}$ (680mg, $71 \%$, mixture of diastereomers as indicated by ${ }^{1} \mathrm{H}$ and ${ }^{31} \mathrm{P} \mathrm{NMR}$ ) as a white foam. TLC: $R_{f} 0.40$ (methylene 
chloride/methanol, 10:1); ${ }^{1} \mathrm{H}$ NMR (DMSO- $d_{6}, 300 \mathrm{MHz}$ ) for diastereomers: $\delta 7.94-$ 7.20 (m, 5H, H-6, Ph-H), 6.81(m, 1H, H-5), 5.92 (m, 1H, H-1'), 5.76 (m, 1H, -CH=), $5.54\left(\mathrm{~m}, 1 \mathrm{H}, \mathrm{D}_{2} \mathrm{O}\right.$ exchangeable, 2'-OH), $5.12\left(\mathrm{q}, 2 \mathrm{H},=\mathrm{CH}_{2}\right), 4.28\left(\mathrm{~m}, 1 \mathrm{H}, \mathrm{D}_{2} \mathrm{O}\right.$ exchangeable, 3'-OH),3.84 (m, 3H, H-4', H-5' and H-5''), 3.42 (m, 4H, H-2', H-3' and $\left.\mathrm{ClCH}_{2}-\right), 2.76\left(\mathrm{~m}, 2 \mathrm{H},-\mathrm{CH}_{2}-\mathrm{N}\right), 2.59\left(\mathrm{~m}, 3 \mathrm{H}, \mathrm{CH}_{3}-\mathrm{N}\right), 1.41\left(\mathrm{~m}, 4 \mathrm{H},-\mathrm{CH}_{2} \mathrm{CH}_{2}-\right) ;{ }^{31} \mathrm{P}$ NMR $\left(\mathrm{CDCl}_{3}, 121 \mathrm{MHz}\right) \delta$-12.76, -13.62 (1:1); MS (ESI): 628/630 [M+H] $]^{+}$HRMS (ESI): calcd for $\mathrm{C}_{24} \mathrm{H}_{32} \mathrm{ClN}_{7} \mathrm{O}_{9} \mathrm{P} 628.1688[\mathrm{M}+\mathrm{H}]^{+}$, found 628.1683 .

5'-Uridyl benzyl $N$-methyl- $N$-(4-chlorobutyl) phosphoramidate (4c). To a solution of benzyl alcohol (162 mg, $1.5 \mathrm{mmol})$ in THF (2.5 mL) was added LiHMDS (1M solution in THF, $1.5 \mathrm{~mL}, 1.5 \mathrm{mmol}$ ) dropwise at $-78{ }^{\circ} \mathrm{C}$ under argon, and the resulting solution was stirred at $-78{ }^{\circ} \mathrm{C}$ for $20 \mathrm{~min}$. Then the above alkoxide solution was canulated to a solution of $9 \mathrm{c}(293 \mathrm{mg}, 0.5 \mathrm{mmol})$ in THF $(5 \mathrm{~mL})$ at $-78{ }^{\circ} \mathrm{C}$, and the reaction mixture was stirred under argon for $2 \mathrm{~h}$, during which the temperature was gradually warmed to 0 ${ }^{\circ} \mathrm{C}$. The reaction was quenched by adding saturated $\mathrm{NH}_{4} \mathrm{Cl}$ solution $(20 \mathrm{~mL})$, and the mixture was extracted with methylene chloride $(2 \times 20 \mathrm{~mL})$. The organic layer was dried over $\mathrm{Na}_{2} \mathrm{SO}_{4}$ and concentrated to give crude $10 \mathrm{c}$ as a syrup.

Crude 10c was dissolved in $10 \mathrm{~mL}$ of $\mathrm{CH}_{3} \mathrm{CN} / \mathrm{H}_{2} \mathrm{O}(1: 1)$, and the $\mathrm{pH}$ of the solution was adjusted to 2.0 with $1 \mathrm{M} \mathrm{HCl}$. The reaction mixture was stirred at room temperature for 4 $\mathrm{h}$, then the $\mathrm{pH}$ was adjusted to 8.0 with $\mathrm{NH}_{4} \mathrm{HCO}_{3}$ and the mixture was stirred for another $2 \mathrm{~h}$. $\mathrm{CH}_{3} \mathrm{CN}$ was removed in vacuo and the resulting aqueous solution was lyophilized to dryness. The residue was purified by silica gel chromatography (methylene chloride/methanol, 20:1 to 10: 1) to give 4 c (215 $\mathrm{mg}, 69 \%$, mixture of diastereomers as indicated by ${ }^{1} \mathrm{H}$ and ${ }^{31} \mathrm{P}$ NMR) as a white foam. TLC: $R f \quad 0.37$ (methylene chloride/methanol, 10:1); ${ }^{1} \mathrm{H} \mathrm{NMR}\left(\mathrm{CDCl}_{3}, 300 \mathrm{MHz}\right)$ for diastereomers: $\delta 10.14$ (br s, 1H, H-3), 7.59 (dd, 1H, H-6), 7.33 (m, 5H, Ph-H), 5.83 (m, 1H, H-5), 5.56 (dd, 1H, H1'), 4,97 (m 2H, Ph- $\mathrm{CH}_{2}-$ ), 4.36 - 4.10 (m, 5H, H-2', H-3', H-4', H-5' and H-5' '), 3.49 (m, 2H, $\left.\mathrm{ClCH}_{2}-\right), 2.98\left(\mathrm{~m}, 2 \mathrm{H},-\mathrm{CH}_{2}-\mathrm{N}\right), 2.56\left(\mathrm{dd}, 3 \mathrm{H}, \mathrm{CH}_{3}-\mathrm{N}\right), 1.70-1.60(\mathrm{~m}, 4 \mathrm{H}$, $\left.-\mathrm{CH}_{2} \mathrm{CH}_{2}-\right) ;{ }^{31} \mathrm{P} \quad \mathrm{NMR} \quad\left(\mathrm{CDCl}_{3}, 121 \mathrm{MHz}\right) \quad \delta \quad-14.09,-14.19 \quad(1: 1$ mixture of diastereomers). MS (ESI): 518/520 [M +H] $]^{+}$; Anal. calcd for $\mathrm{C}_{21} \mathrm{H}_{29} \mathrm{ClN}_{3} \mathrm{O}_{8} \mathrm{P}: \mathrm{C}, 48.70$; H, 5.64; N, 8.11. found: C, 48.53; H, 5.76; N, 7.81. 


\section{5'-[1-( $\beta-D-2$ ',3'-O-Methoxymethylidene-ribofuranosyl)-1,2,4-triazole-3-}

carboxamide] benzyl $N$-methyl- $N$-(4-chlorobutyl) phosphoramidate (4d). To a solution of 9d (290 mg, $0.5 \mathrm{mmol})$ and benzyl alcohol $(2.7 \mathrm{~g}, 25 \mathrm{mmol})$ in THF (2.5 mL) was added DMAP (244 mg, $2.0 \mathrm{mmol}$ ) and the reaction mixture was stirred at room temperature overnight under argon. Solvent was removed in vacuo and the residue was purified by silica gel chromatography (methylene chloride/methanol, 20:1) to give crude 10d as a syrup.

Crude 10d was dissolved in $20 \mathrm{~mL}$ of $\mathrm{CH}_{3} \mathrm{CN} / \mathrm{H}_{2} \mathrm{O}(1: 1)$, and the $\mathrm{pH}$ of the solution was adjusted to 2.0 with $1 \mathrm{M} \mathrm{HCl}$. The reaction mixture was stirred at room temperature for $1 \mathrm{~d}$, then the $\mathrm{pH}$ was adjusted to 8.0 with $\mathrm{NH}_{4} \mathrm{HCO}_{3}$ and the mixture was stirred for another $1 \mathrm{~d}$. $\mathrm{CH}_{3} \mathrm{CN}$ was removed in vacuo and the resulting aqueous solution was lyophilized to dryness. The residue was purified by silica gel chromatography (methylene chloride/methanol, 10:1) to give 4d (180 mg, 69\%, mixture of diastereomers as indicated by ${ }^{1} \mathrm{H}$ and ${ }^{31} \mathrm{P}$ NMR) as a white foam. TLC: $R_{f} 0.22$ (methylene chloride/methanol, 10:1); ${ }^{1} \mathrm{H}$ NMR $\left(\mathrm{CDCl}_{3}\right)$ for diastereomers: $\delta 10.14$ (br s, 1H, H-3), TLC: Rf 0.37 (methylene chloride/methanol, 10:1); ${ }^{1} \mathrm{H}$ NMR $\left(\mathrm{DMSO}_{6}, 300 \mathrm{MHz}\right)$ for diastereomers: $\delta 8.68(\mathrm{~d}$, 1H, H-5), 7.73, 7.50, (2 s, 2H, $\mathrm{D}_{2} \mathrm{O}$ exchangeable, $\left.\mathrm{CONH}_{2}\right), 7.22(\mathrm{~m}, 5 \mathrm{H}, \mathrm{Ph}-\mathrm{H}), 5.76(\mathrm{t}$, $1 \mathrm{H}, \mathrm{H}-1$ ') 5.55 (d, 1H, $\mathrm{D}_{2} \mathrm{O}$ exchangeable, 2'-OH), 5.25 (d, 1H, $\mathrm{D}_{2} \mathrm{O}$ exchangeable, 3'$\mathrm{OH}), 4.76$ (d, 2H, Ph- $\mathrm{CH}_{2}-$ ), 4.22- 4.14 (m, 2H, H-2', H-3'), 3.94 (m, 2H, H-5', H-5' '), 3.83(m, 1H, H-4'), 3.46 (m, 2H, $\left.\mathrm{ClCH}_{2}-\right), 2.74\left(\mathrm{~m}, 2 \mathrm{H},-\mathrm{CH}_{2}-\mathrm{N}\right), 2.34$ (t, 3H, $\left.\mathrm{CH}_{3}-\mathrm{N}\right)$, 1.52-1.36 (m, 4H, $\left.-\mathrm{CH}_{2} \mathrm{CH}_{2}-\right) ;{ }^{31} \mathrm{P}$ NMR ( $\left.\mathrm{CD}_{3} \mathrm{OD}, 121 \mathrm{MHz}\right): \delta$-13.90, -14.00 (1:1 mixture of diastereomers); MS (ESI): 518/520 [M+H] $]^{+}, 540 / 542[\mathrm{M}+\mathrm{Na}]^{+}$; HRMS (ESI): calcd for $\mathrm{C}_{20} \mathrm{H}_{29} \mathrm{ClN}_{5} \mathrm{NaO}_{7} \mathrm{P} 540.1391[\mathrm{M}+\mathrm{Na}]^{+}$, found 540.1402.

\section{5'-[ $N^{4}$-(Allyloxycarbonyl)cytosine arabinosyl] benzyl $N$-methyl- $N$-(4-chlorobutyl)} phosphoramidate (10e). To a solution of 9 e $(490 \mathrm{mg}, 0.78 \mathrm{mmol})$ and benzyl alcohol (4.2 g, $39 \mathrm{mmol})$ in THF $(0.5 \mathrm{~mL})$ was added DMAP (380 mg, $3.12 \mathrm{mmol})$, and the reaction mixture was stirred at room temperature overnight under argon. Solvent was removed in vacuo, and the residue was purified by silica gel chromatography (methylene chloride/methanol, 20:1 to $10: 1)$ to give $10 \mathrm{e}$ (340 $\mathrm{mg}, 68 \%$, mixture of diastereomers as indicated by ${ }^{1} \mathrm{H}$ NMR and ${ }^{31} \mathrm{P} \mathrm{NMR}$ ) as a white foam. TLC: $R_{f} 0.22$ (methylene chloride/methanol, 10:1); ${ }^{1} \mathrm{H}$ NMR (DMSO- $d_{6}, 300 \mathrm{MHz}$ ) for diastereomers: $\delta 10.76$ (br 
s, 1H, D $2 \mathrm{O}$ exchangeable, 4-NH), 8,07 (t, 1H, H-6), 7.36 (m, 5H, Ph-H), $6.98(\mathrm{~m}, 1 \mathrm{H}, \mathrm{H}-$ 5), 6.10 (m, 1H, H-1'), $5.94(\mathrm{~m}, 1 \mathrm{H},-\mathrm{CH}=), 5.64\left(\mathrm{~m}, 1 \mathrm{H}, \mathrm{D}_{2} \mathrm{O}\right.$ exchangeable, 2'-OH), $5.30\left(\mathrm{q}, 2 \mathrm{H},=\mathrm{CH}_{2}\right), 4.93\left(\mathrm{~m}, 2 \mathrm{H}, \mathrm{Ph}-\mathrm{CH}_{2}-\right), 4.62\left(\mathrm{~m}, 2 \mathrm{H}, \mathrm{O}-\mathrm{CH}_{2}-\mathrm{CH}=\right), 4.18-3.93$ (m, 5H, H-2', H-3' H-4', H-5' and H-5' '), 3.32 (m, 2H, $\mathrm{ClCH}_{2}-$ ), 2.96 (m, 2H, $\left.-\mathrm{CH}_{2}-\mathrm{N}\right)$, $2.53\left(\mathrm{~m}, 3 \mathrm{H}, \mathrm{CH}_{3}-\mathrm{N}\right), 1.67-1.56\left(\mathrm{~m}, 4 \mathrm{H},-\mathrm{CH}_{2} \mathrm{CH}_{2}-\right)$; ${ }^{31} \mathrm{P} \mathrm{NMR}\left(\mathrm{CD}_{3} \mathrm{OD}, 121 \mathrm{MHz}\right) \delta$ -13.52, -13.75 (1:1 mixture of diastereomers); MS (ESI): 601/603 [M+H] $]^{+}$; HRMS (ESI): calcd for $\mathrm{C}_{25} \mathrm{H}_{35} \mathrm{ClN}_{4} \mathrm{O}_{9} \mathrm{P} 601.1830[\mathrm{M}+\mathrm{H}]^{+}$, found 601.1840 .

5'-Cytosine arabinosyl benzyl $N$-methyl- $N$-(4-chlorobutyl) phosphoramidate (4e). $\mathrm{Pd}\left(\mathrm{PPh}_{3}\right)_{4}(26 \mathrm{mg}, 0.02 \mathrm{mmol})$ was added to a solution of $10 \mathrm{e}(270 \mathrm{mg}, 0.45 \mathrm{mmol})$ and in THF ( $2 \mathrm{~mL}$ ), followed by the addition of p-toluenesulfinic acid sodium salt ( $88 \mathrm{mg}, 0.5$ mmol) in double distilled water $(1 \mathrm{~mL})$. The reaction mixture was stirred at room temperature for $1 \mathrm{~h}$. Solvent was removed in vacuo, and the residue was purified by silica gel chromatography (methylene chloride/methanol, 10:1 to 5:1) to give 4 e $(210 \mathrm{mg}$, $90 \%$, mixture of diastereomers as indicated by ${ }^{1} \mathrm{H}$ NMR and ${ }^{31} \mathrm{P}$ NMR) as a white foam. TLC: $R_{f} 0.1$ (methylene chloride/methanol, 10:1); ${ }^{1} \mathrm{H}$ NMR (DMSO- $d_{6}, 300 \mathrm{mHz}$ ) for diastereomers: $\delta 7.56(\mathrm{t}, 1 \mathrm{H}, \mathrm{H}-6), 7.36(\mathrm{~m}, 5 \mathrm{H}, \mathrm{Ph}-\mathrm{H}), 7.10,7.02\left(2 \mathrm{br} \mathrm{s}, 2 \mathrm{H}, \mathrm{D}_{2} \mathrm{O}\right.$ exchangeable, 4- $\left.\mathrm{NH}_{2}\right), 6.10\left(\mathrm{~m}, 1 \mathrm{H}, \mathrm{H}-1^{\prime}\right), 5.65(\mathrm{t}, 1 \mathrm{H}, \mathrm{H}-5), 5.55\left(\mathrm{~m}, 2 \mathrm{H}, \mathrm{D}_{2} \mathrm{O}\right.$ exchangeable, 2'-OH, 3'-OH), 4.92 (m, 2H, $\mathrm{Ph}-\mathrm{CH}_{2}-$ ), 4.08 - 3.89 (m, 5H, H-2', H-3' H-4', H-5' and H-5' '), $3.62\left(\mathrm{~m}, 2 \mathrm{H}, \mathrm{ClCH}_{2}-\right), 2.96\left(\mathrm{~m}, 2 \mathrm{H},-\mathrm{CH}_{2}-\mathrm{N}\right), 2.52(\mathrm{~m}, 3 \mathrm{H}$, $\left.\mathrm{CH}_{3}-\mathrm{N}\right), 1.69-1.56\left(\mathrm{~m}, 4 \mathrm{H},-\mathrm{CH}_{2} \mathrm{CH}_{2}-\right)$; ${ }^{31} \mathrm{P} \mathrm{NMR}\left(\mathrm{CD}_{3} \mathrm{OD}, 121 \mathrm{MHz}\right) \delta-13.58$, 13.78 (1:1 mixture of diastereomers); MS (ESI): 517/519 [M+H] ${ }^{+}$; HRMS (ESI): calcd for $\mathrm{C}_{21} \mathrm{H}_{31} \mathrm{ClN}_{4} \mathrm{O}_{7} \mathrm{P} 517.1619[\mathrm{M}+\mathrm{H}]^{+}$, found 517.1617 .

A General procedure for the synthesis of nucleoside triphosphates from nucleoside 5' benzyl $N$-methyl- $N$-(4-chlorobutyl) phosphoramidates. Nucleoside 5' benzyl $N$-methyl- $N$-(4-chlorobutyl) phosphoramidate was dissolved in $5 \mathrm{~mL}$ of anhydrous THF or DMF, palladium catalyst $\left(10 \% \mathrm{Pd} / \mathrm{C}\right.$ or $\left.5 \% \mathrm{Pd} / \mathrm{Al}_{2} \mathrm{O}_{3}\right)$ was added and the mixture was stirred under one atmosphere of $\mathrm{H}_{2}$ at room temperature. After the hydrogenolysis was complete as indicated by TLC and ${ }^{31} \mathrm{P}$ NMR, the hydrogen was replaced by argon, and the reaction mixture was filtered though a $0.45 \mu \mathrm{m}$ syringe filter to remove the catalyst then rinsed once with $5 \mathrm{~mL}$ same solvent. To the combined filtrate was added tris(tetra- $n$-butylammonium) hydrogen pyrophosphate (1.0 equiv), and the 
mixture was stirred for $30 \mathrm{~min}$ at room temperature. For reactions run in THF, the solvent was removed in vacuo and the residue was dissolved in $5 \mathrm{~mL}$ of aqueous $\mathrm{NH}_{4} \mathrm{HCO}_{3}(50 \mathrm{mM})$. For reactions run in DMF, the reaction mixture was directly diluted with $5 \mathrm{~mL} 50 \mathrm{mM} \mathrm{NH} \mathrm{HCO}_{3}$ solution. The resulting solution was purified by a linear gradient elution on a Q Sepharose FF anion exchange column $\left(2.5 \mathrm{~cm} \times 20 \mathrm{~cm}, \mathrm{HCO}_{3}{ }^{-}\right.$ form) with $\mathrm{NH}_{4} \mathrm{HCO}_{3}(0.05-0.5 \mathrm{M}, \mathrm{pH} 7.8)$ at a flow rate of $5 \mathrm{~mL} / \mathrm{min}$ over $2 \mathrm{~h}$ using UV detection at $254 \mathrm{~nm}$. The desired fractions were dried by lyophilization to yield nucleoside triphosphate as a white fluffy powder.

Thymidine 5'-triphosphate (5a). Following the general procedure, thymidine phosphoramidate 4a $(72 \mathrm{mg}, 0.14 \mathrm{mmol})$ underwent hydrogenolysis with $\mathrm{Pd} / \mathrm{C}(10 \%, 25$ $\mathrm{mg})$ in THF for $2 \mathrm{~h}$, then reacted with TBAPP (126 mg, $0.14 \mathrm{mmol})$ to give thymidine 5'triphosphate $\mathbf{5 a}(52 \mathrm{mg}, 77 \%)$ as a white fluffy powder which is identical to the commercial sample in all respects.

2'-Deoxycytidine 5'-triphosphate (5b). Following the general procedure, 2'deoxycytidine phosphoramidate $4 \mathbf{b}(50 \mathrm{mg}, 0.1 \mathrm{mmol})$ underwent hydrogenolysis with $\mathrm{Pd} /$ alumina $(5 \%, 21 \mathrm{mg})$ in DMF for $1 \mathrm{~h}$, then reacted with TBAPP $(90 \mathrm{mg}, 0.1 \mathrm{mmol})$ to give 2'deoxycytidine 5'-triphosphate $\mathbf{5 b}(35 \mathrm{mg}, 75 \%)$ as a white fluffy powder which is identical to the commercial sample in all respects.

Uridine 5'-triphosphate $\mathbf{( 5 c )}$. Following the general procedure, uridine phosphoramidate $4 \mathbf{c}(70 \mathrm{mg}, 0.135 \mathrm{mmol})$ underwent hydrogenolysis with $\mathrm{Pd} / \mathrm{C}(10 \%, 25$ $\mathrm{mg})$ in THF for $2 \mathrm{~h}$, then reacted with TBAPP $(122 \mathrm{mg}, 0.135 \mathrm{mmol})$ to give uridine 5'triphosphate 5c (45 $\mathrm{mg}, 69 \%)$ as a white fluffy powder which is identical to the commercial sample in all respects.

1-( $\beta$-D-Ribofuranosyl)-1,2,4-triazole-3-carboxamide 5'-triphosphate (ribavirin 5'-

triphosphate, 5d). Following the general procedure, ribavirin phosphoramidate $4 \mathbf{d}$ (80 $\mathrm{mg}, 0.15 \mathrm{mmol}$ ) underwent hydrogenolysis with Pd/alumina (5\%, $32 \mathrm{mg}$ ) in DMF for $1 \mathrm{~h}$, then reacted with TBAPP $(135 \mathrm{mg}, 0.15 \mathrm{mmol})$ to give ribavirin 5 '-triphosphate $\mathbf{5 d}$ (51 $\mathrm{mg}, 71 \%)$ as a white fluffy powder. HPLC: $12.35 \mathrm{~min} .{ }^{1} \mathrm{H} \mathrm{NMR}\left(\mathrm{D}_{2} \mathrm{O}, 300 \mathrm{MHz}\right): 8.68$ (s, 1H, H-5), 5.89 (d, J=3.6 Hz, 1H, H-1'), 4.45 (m, 1H, H-3'), 4.24 (m, 1H, H-4'), 4.08 (m, 2H, H-5', H-5"). ${ }^{13} \mathrm{C}$ NMR ( $\left.\mathrm{D}_{2} \mathrm{O}, 75 \mathrm{MHz}\right): 163.1,156.6,146.1,92.2,84.2\left(J_{C, P}=\right.$ $8.1 \mathrm{~Hz}), 74.9,70.2,65.3 .{ }^{31} \mathrm{P}$ NMR $\left(\mathrm{D}_{2} \mathrm{O}, 121 \mathrm{MHz}\right)$ : $-31.28\left(\mathrm{~d}, J_{p, p}=19.4 \mathrm{~Hz}\right),-36.17$ (d, 
$\left.J_{p, p}=19.4 \mathrm{~Hz}\right),-46.98\left(\mathrm{t}, J_{p, p}=19.4 \mathrm{~Hz}\right)$. HRMS (ESI): calcd for $\mathrm{C}_{8} \mathrm{H}_{16} \mathrm{~N}_{4} \mathrm{O}_{14} \mathrm{P}_{3} 484.9876$ $[\mathrm{M}+\mathrm{H}]^{+}$, found: $484.9875[\mathrm{M}+\mathrm{H}]^{+}$.

Cytosine arabinoside 5'-triphosphate (5e). 5e was synthesized using a slight modification of the general procedure. Cytosine arabinoside phosphoramidate $4 \mathbf{e}(120 \mathrm{mg}$, $0.23 \mathrm{mmol})$ underwent hydrogenolysis with $\mathrm{Pd} /$ alumina $(5 \%, 50 \mathrm{mg})$ in DMF $(5 \mathrm{~mL})$ for $1 \mathrm{~h}$, double distilled water $(0.5 \mathrm{~mL})$ was added and the mixture was filtered. To the filtration TBAPP (207 mg, $0.23 \mathrm{mmol}$ ) was added and the reaction was stirred for $4 \mathrm{~h}$. Same workup and purification gave cytosine arabinoside 5'-triphosphate $\mathbf{5 e}(61 \mathrm{mg}, 55 \%)$ as a white fluffy powder. HPLC: $12.32 \mathrm{~min} .{ }^{1} \mathrm{H}$ NMR $\left(\mathrm{D}_{2} \mathrm{O}, 300 \mathrm{MHz}\right): 7.68(\mathrm{~d}, J=7.8$ Hz, 1H, H-6), 6.07 (d, $J=4.8 \mathrm{~Hz}, 1 \mathrm{H}, \mathrm{H}-1$ '), 5.92 (d, $J=7.8 \mathrm{~Hz}, 1 \mathrm{H}, \mathrm{H}-5), 4.28$ (m, 1H, H-2'), 3.99 (m, 1H, H-3'), 3.88 (m, 1H, H-4'), 3.76 (m, 2H, H-5', H-5' '). ${ }^{13} \mathrm{C}$ NMR ( ${ }_{2} \mathrm{O}$, $75 \mathrm{MHz}): 165.5,156.6,143.4,95.9,85.6,81.4\left(J_{C, P}=8.8 \mathrm{~Hz}\right), 75.7,74.1,64.4 .{ }^{31} \mathrm{P}$ NMR $\left(\mathrm{D}_{2} \mathrm{O}, 121 \mathrm{MHz}\right):-34.37\left(\mathrm{~d}, J_{p, p}=19.4 \mathrm{~Hz}\right),-36.26\left(\mathrm{~d}, J_{p, p}=19.4 \mathrm{~Hz}\right),-47.78\left(\mathrm{t}, J_{p, p}=\right.$ $19.4 \mathrm{~Hz}$ ). HRMS (ESI): calcd for $\mathrm{C}_{9} \mathrm{H}_{17} \mathrm{~N}_{3} \mathrm{O}_{14} \mathrm{P}_{3} 483.9923[\mathrm{M}+\mathrm{H}]^{+}$, found: 483.9924 $[\mathrm{M}+\mathrm{H}]^{+}$. 

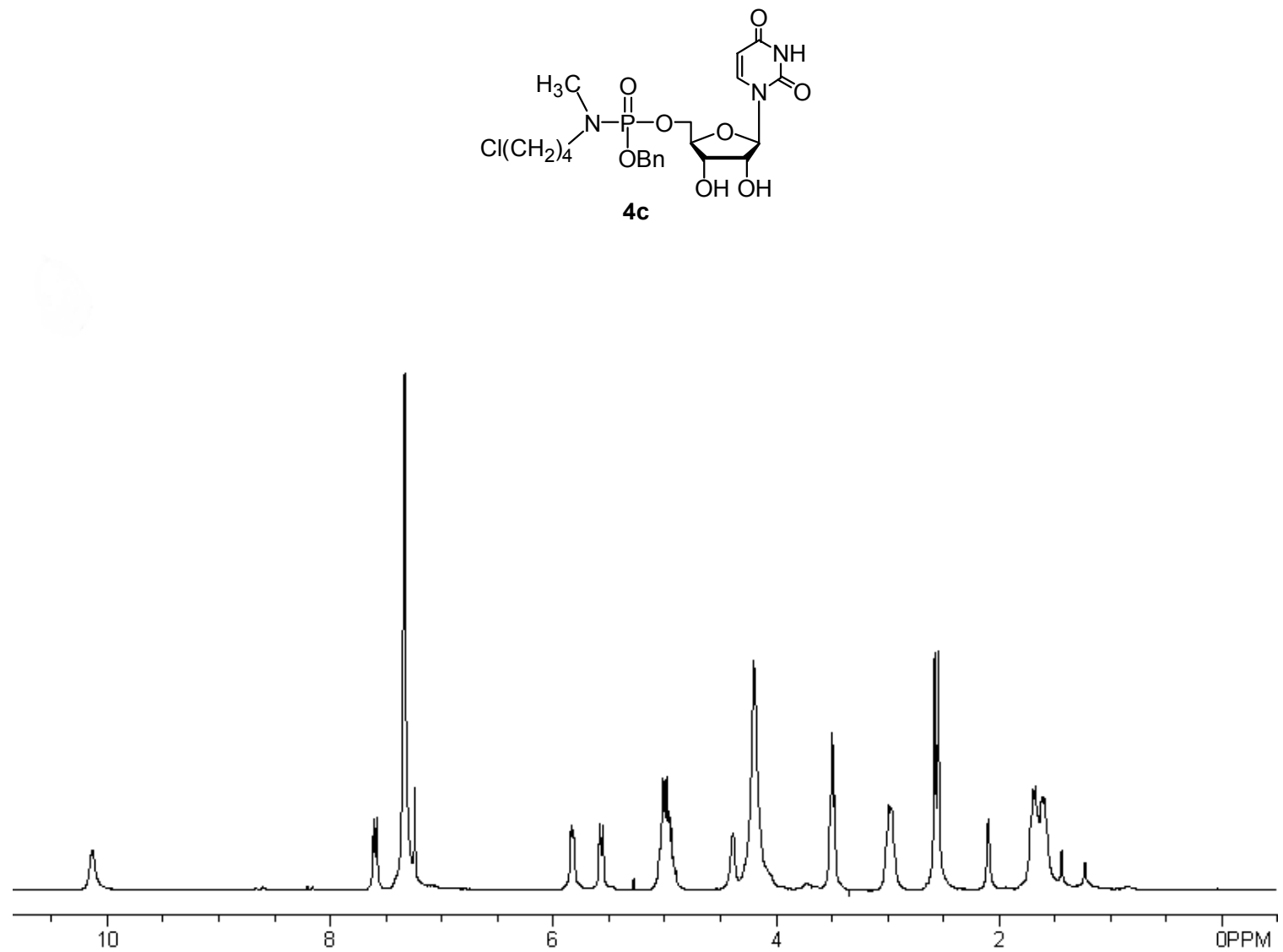

${ }^{1} \mathrm{H}$ NMR spectrum

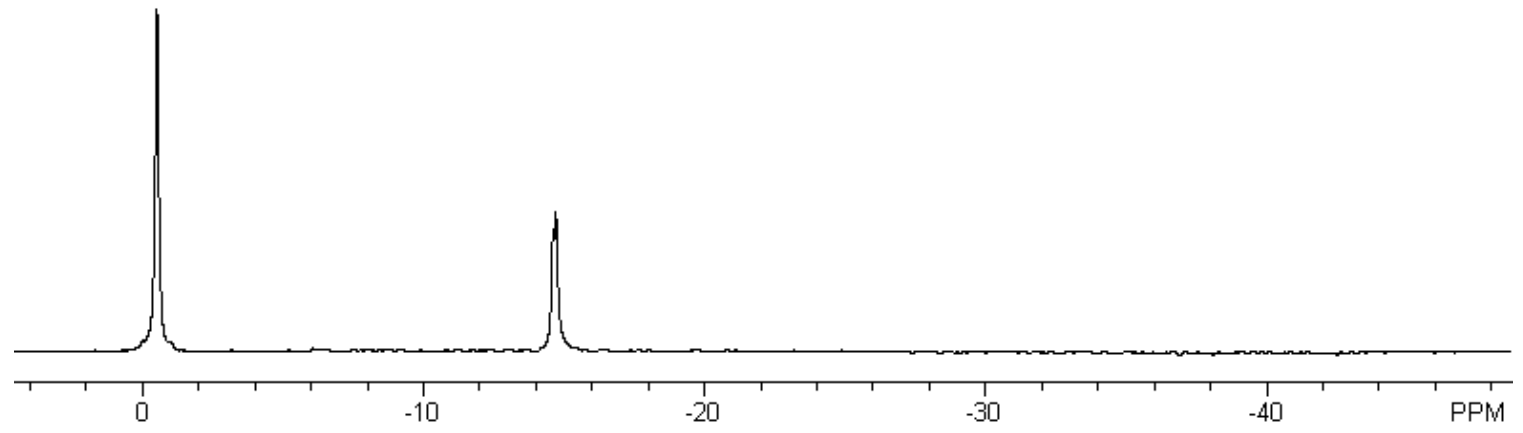

${ }^{31} \mathrm{P}$ NMR spectrum 

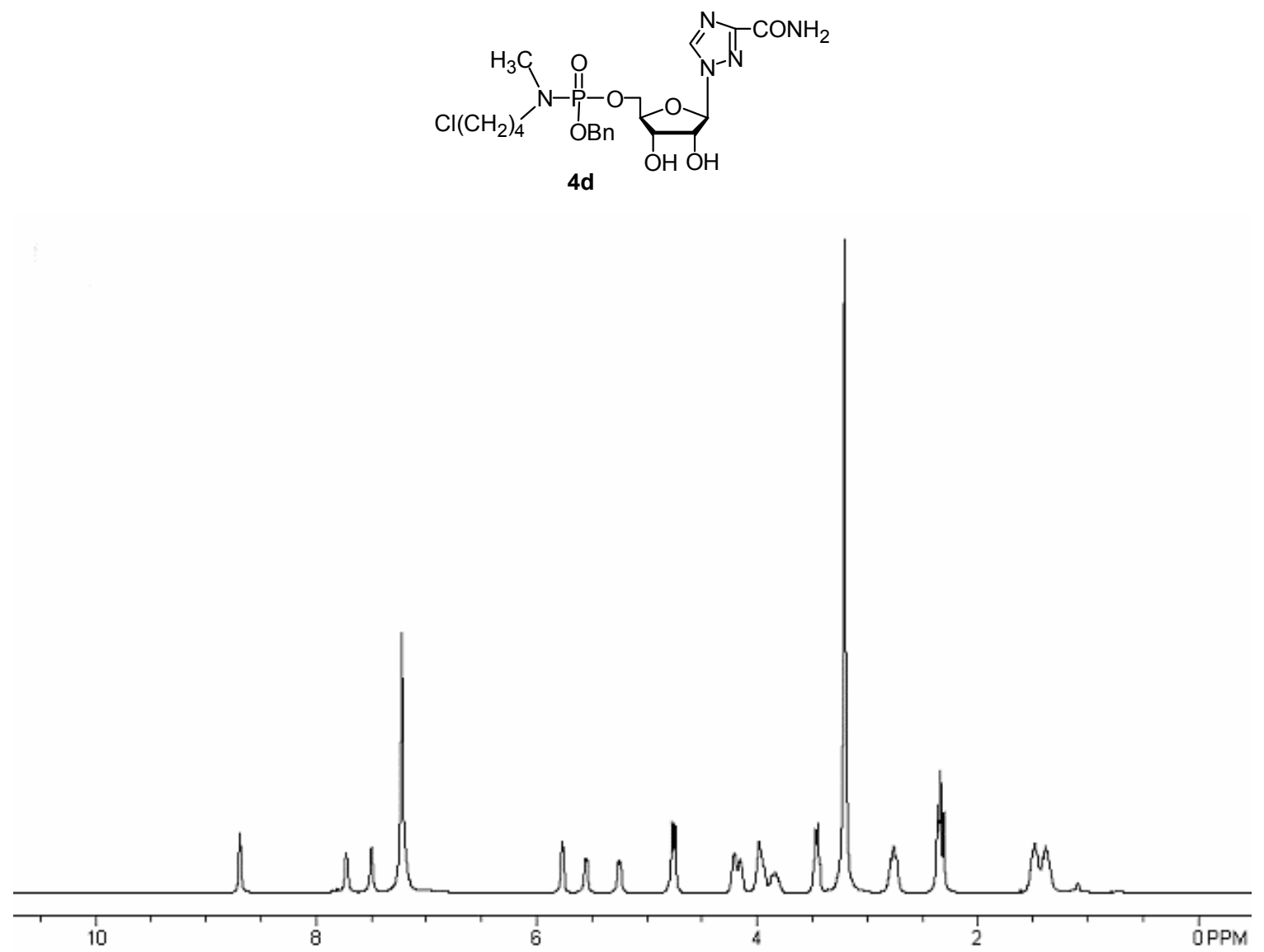

${ }^{1}$ H NMR spectrum

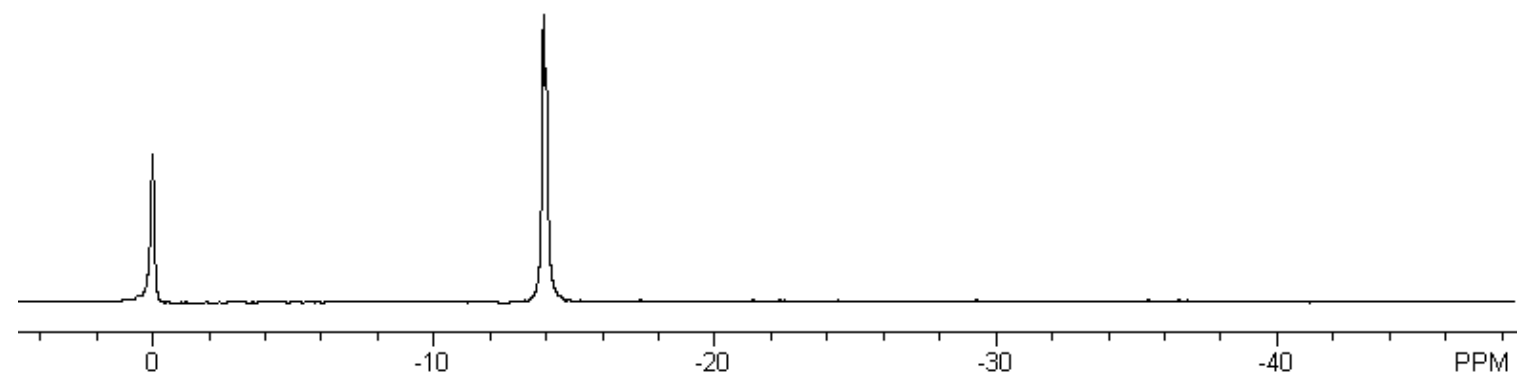

${ }^{31} \mathrm{P}$ NMR spectrum 


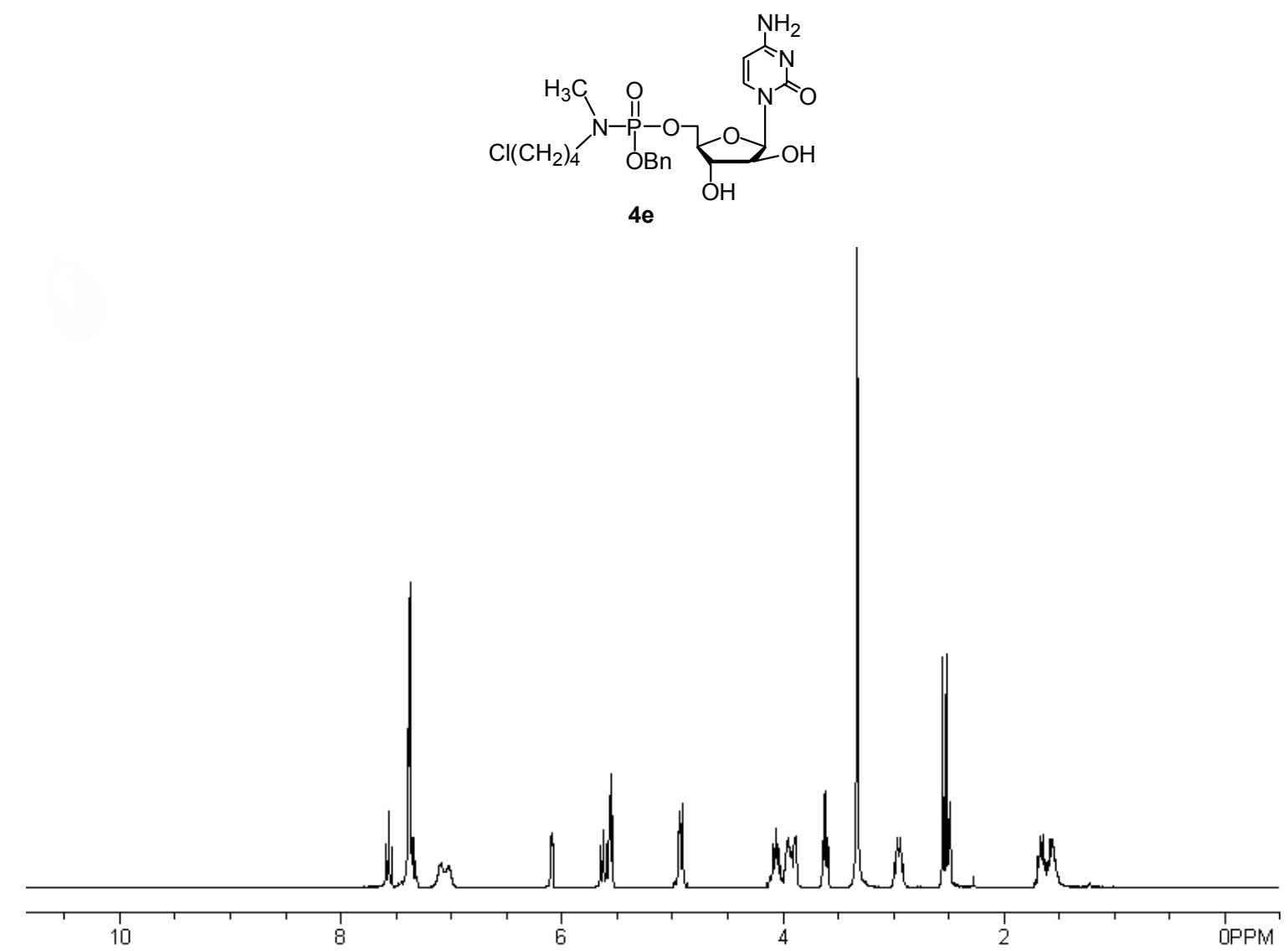

${ }^{1} \mathrm{H}$ NMR spectrum

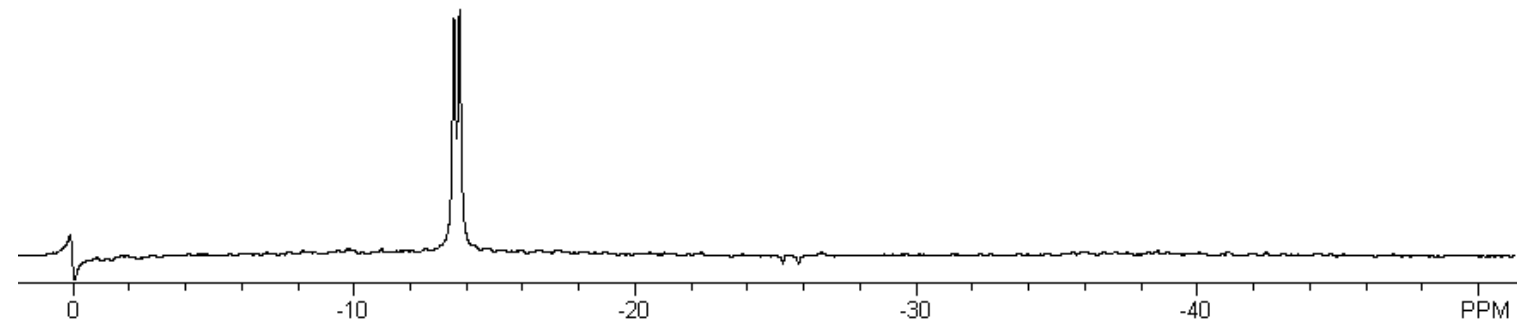

${ }^{31} \mathrm{P}$ NMR spectrum 

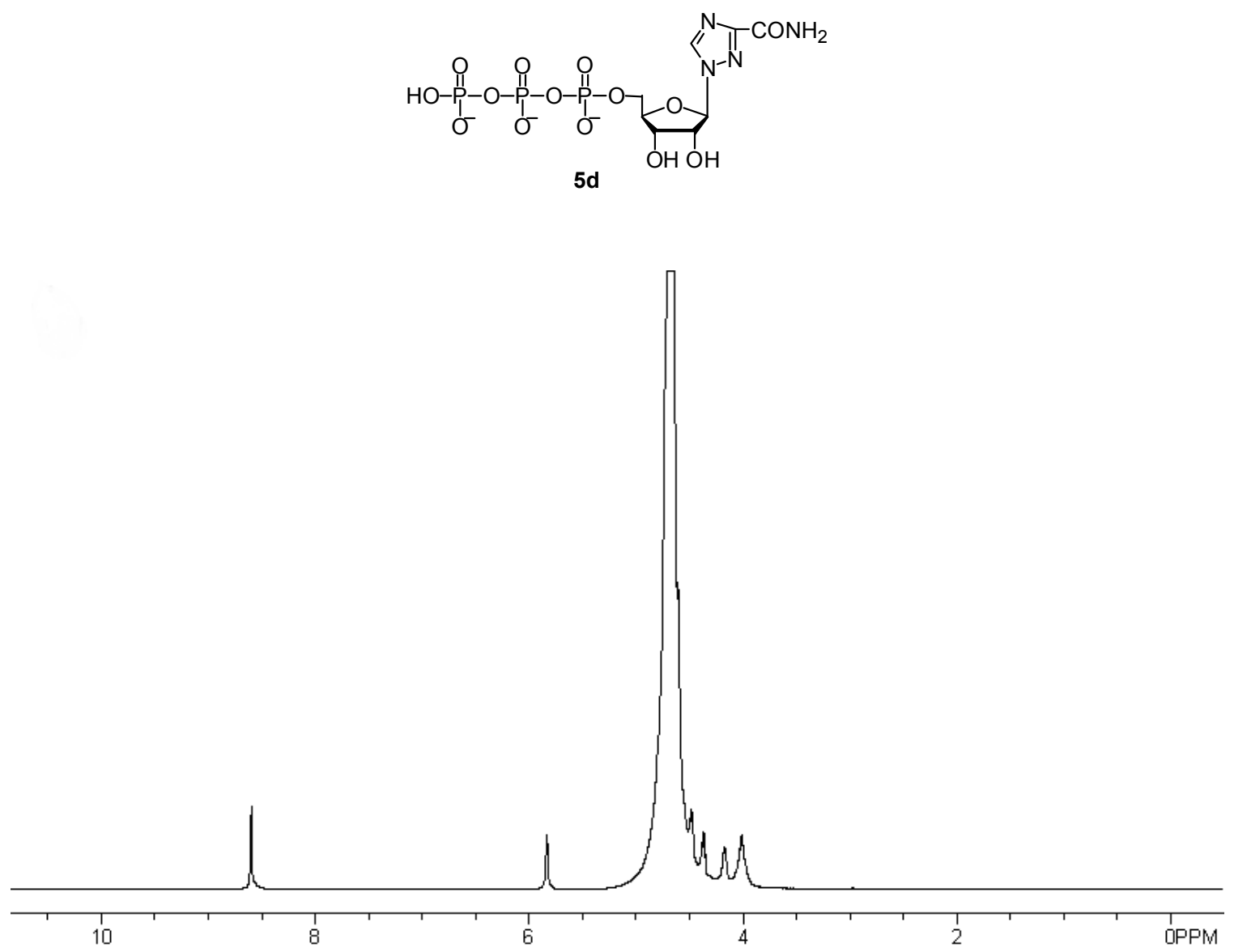

${ }^{1} \mathrm{H}$ NMR spectrum

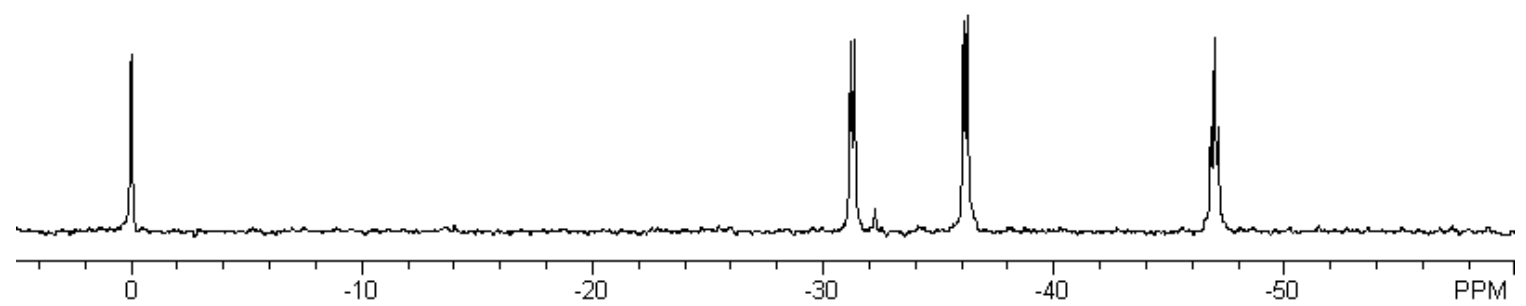

${ }^{31} \mathrm{P}$ NMR spectrum 


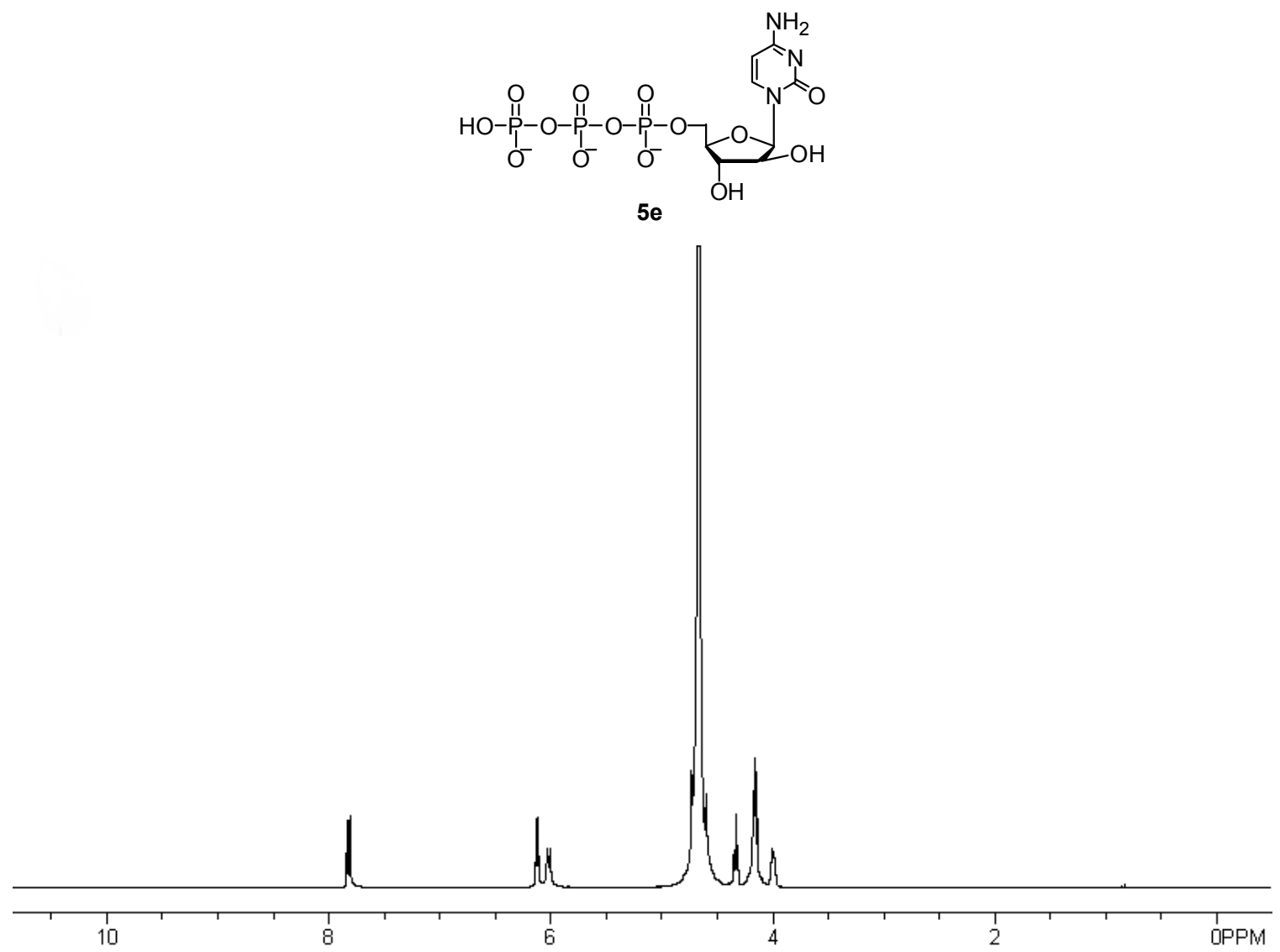

${ }^{1} \mathrm{H}$ NMR spectrum

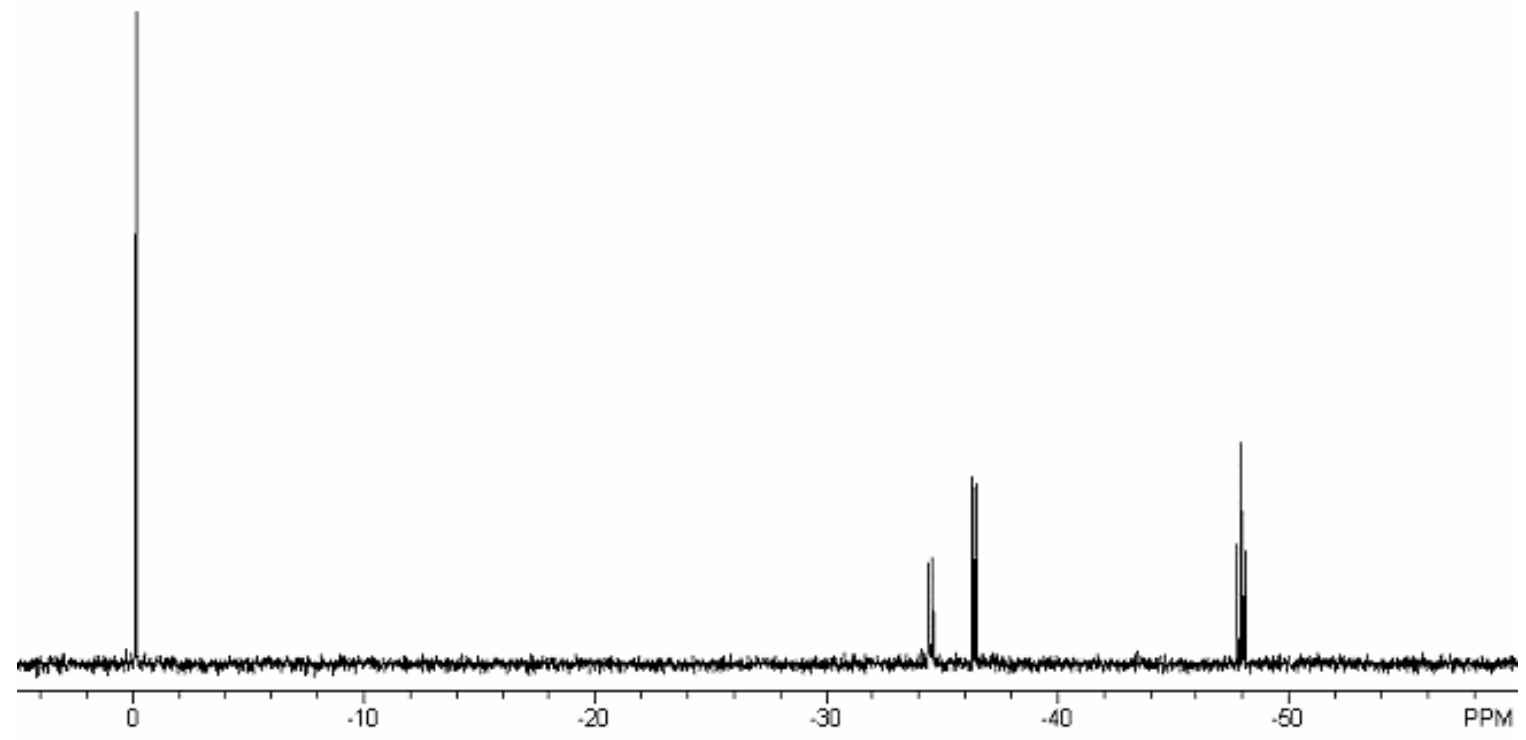

${ }^{31} \mathrm{P}$ NMR spectrum 
Compound 5d HPLC

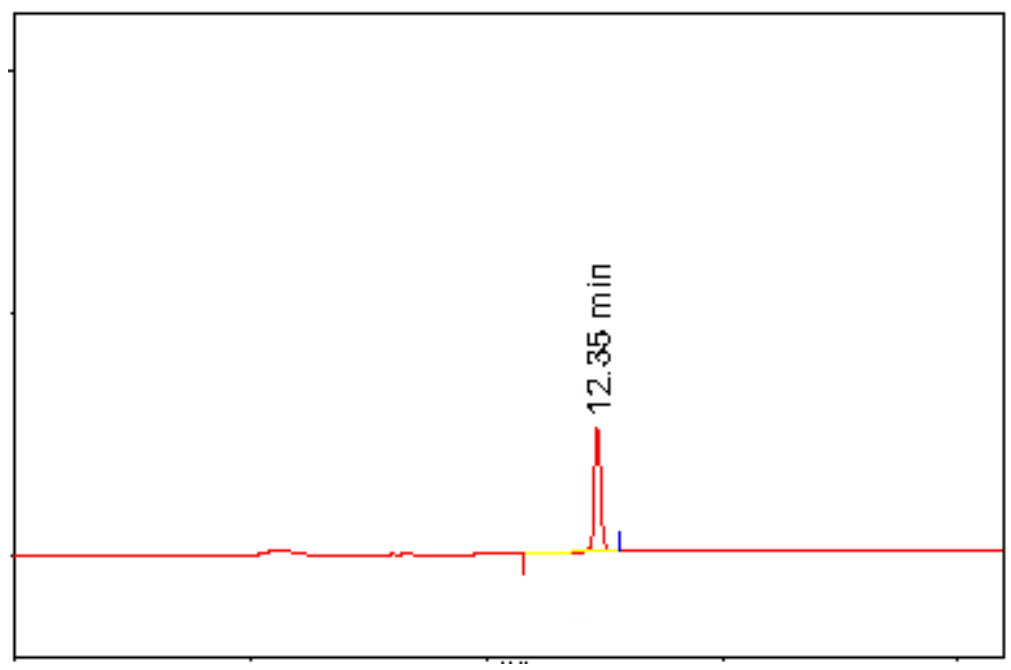

Compound 5e HPLC

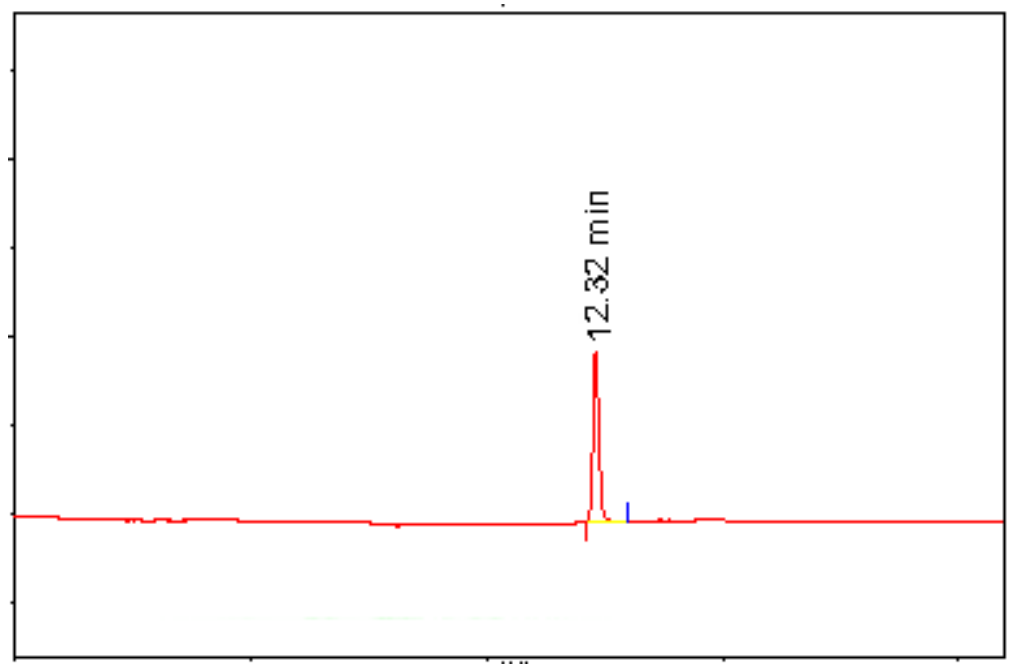

